\title{
KEWENANGAN PEMERINTAH KABUPATEN/KOTA DALAM BIDANG PERTANAHAN*
}

\author{
Urip Santoso \\ Fakultas Hukum Universitas Airlangga \\ Email : urip_sts@yahoo.com
}

\begin{abstract}
The Law No. 5 of 1960 on National Agrarian Law explicitly stipulates that the authority in agrarian issues is the property of the State (Central Government). However, this authority - as stipulated in the Presidential Decree PP No. 38 2007-is transferable from the Central Government to Local Governments. The Law specifies 9 features of agrarian authorities which are transferable to municipal governments. In this respect, the National Land Agency (BPN) is the authorized body which is in charge of the agrarian registration-related matters.
\end{abstract}

Keywords : Authority, Local Government, Agrarian

\begin{abstract}
Abstrak
Dalam Hukum Tanah Nasional yang diatur dalam undang-undang No. 5 Tahun 1960, secara tersirat ditetapkan bahwa Kewenangan di bidang Pertanahan merupakan Kewanangan Pemerintah Pusat. Kewenangan tersebut dapat dilimpahkan kepada Pemerintah Daerah dalam PP No. 38 Tahun 2007 ditetapkan bahwa ada 9 kewenangan di bidang Pertanahan yang di serahkan kepada Pemerintah Kabupaten/Kota. Kewenangan di bidang Pendaftaran Tanah tetap dilaksanakan oleh Badan Pertanahan Nasional.
\end{abstract}

Kata Kunci : Kewenangan, Pemerintah Daerah, Pertanahan

\section{PENDAHULUAN}

Ketentuan-ketentuan pokok tentang pertanahan di Indonesia diatur dalam Undang-undang No. 5 Tahun 1960 tentang Peraturan Dasar Pokok-pokok Agraria, atau yang lebih dikenal dengan sebutan Undang-undang Pokok Agraria (UUPA). Undang-undang ini berlaku sejak tanggal 24 September 1960 dan ketentuanketentuan yang diatur dalam UUPA hanya ketentuan pokoknya, sehingga masih perlu diatur lebih lanjut dalam bentuk peraturan perundang-undangan. Dengan diundangkannya UUPA, maka berlaku Hukum Tanah Nasional yang menyatakan tidak berlaku lagi (mencabut) peraturan dan keputusan yang dibuat oleh

\footnotetext{
*Artikel Ini Merupakan Hasil Penelitian Penulis yang Dibiayai Oleh SP3 Fakultas Hukum Universitas Airlangga Tahun 2011.
} 
Pemerintah Hindia Belanda. Pasal 33 ayat (3) Undang-undang Dasar 1945 menjadi dasar bagi pembentukan UUPA, sebagaimana disebutkan dalam Pasal 2 ayat (1) UUPA.

Dalam UUPA disebutkan ruang lingkup agraria, yaitu meliputi bumi, air, ruang angkasa, dan kekayaan alam yang terkandung di dalamnya. Ruang lingkup bumi, meliputi permukaan bumi (tanah), tubuh bumi, dan ruang yang ada di bawah permukaan air. Dengan demikian, tanah merupakan bagian kecil dari agraria. Tanah yang dimaksudkan disini bukan mengatur tanah dalam segala aspeknya, melainkan hanya mengatur salah satu aspeknya, yaitu tanah dalam pengertian yuridis, yang disebut hak penguasaan atas tanah.

Salah satu hak penguasaan atas tanah dalam UUPA, yaitu hak menguasai Negara atas tanah, yang dimuat dalam Pasal 2 UUPA. Pasal 2 ayat (1) UUPA dinyatakan bahwa bumi, air, ruang angkasa, dan kekayaan alam yang terkandung di dalamnya dikuasai oleh Negara sebagai organisasi kekuasaan seluruh rakyat. Wewenang hak menguasai Negara atas tanah dimuat dalam Pasal 2 ayat (2) UUPA, yaitu :

1. mengatur dan menyelenggarakan peruntukan, penggunaan, persediaan, dan pemeliharaan tanah;

2. menentukan dan mengatur hubungan-hubungan hukum antara orang-orang dengan tanah;

3. menentukan dan mengatur hubungan-hubungan hukum antara orang-orang dan perbuatan-perbuatan hukum yang mengenai tanah.

Pasal 2 ayat (4) UUPA menegaskan bahwa hak menguasai Negara atas tanah dalam pelaksanaannya dapat dikuasakan kepada Daerah-daerah Swatantra dan masyarakat-masyarakat hukum adat sekedar diperlukan dan tidak bertentangan dengan kepentingan nasional menurut ketentuan-ketentuan dalam Peraturan Pemerintah. Berdasarkan ketentuan Pasal 2 ayat (4) UUPA, hak menguasai Negara atas tanah dalam pelaksanaannya dapat dilimpahkan kewenangannya kepada Pemerintah Daerah. Pelimpahan kewenangan tersebut diberikan oleh Negara kepada Pemerintah Daerah sekadar diperlukan dan tidak 
bertentangan dengan kepentingan nasional, yang akan diatur dengan Peraturan Pemerintah.

Secara tersirat dapat dikatakan bahwa atas dasar ketentuan Pasal 2 ayat (4) UUPA, urusan tanah merupakan kewenangan yang sifatnya terpusat yang dilaksanakan oleh Pemerintah Pusat. Namun demikian, kalau diperlukan kewenangan di bidang pertanahan yang sifatnya terpusat tersebut dalam pelaksanaannya dapat dilimpahkan kewenangannya kepada Pemerintah Daerah. Pemerintah Daerah tidak dapat melaksanakan urusan di bidang pertanahan kalau tidak diberikan pelimpahan kewenangan oleh Pemerintah Pusat. Pelaksanaan kewenangan di bidang pertanahan yang sifatnya terpusat oleh Pemerintah Pusat dalam rangka mewujudkan salah satu tujuan dibentuknya, yaitu terwujudnya kesatuan (unifikasi) hukum.

Pada mulanya sejak berlakunya UUPA, kewenangan di bidang administrasi pertanahan dilaksanakan oleh Menteri Agraria, kemudian dilaksanakan oleh Direktur Jenderal Agraria Departemen dalam Negeri. Sejak tahun 1988 dengan diterbitkannya Keputusan Presiden No. 26 Tahun 1988 tentang Badan Pertanahan Nasional (BPN), kewenangan di bidang administrasi pertanahan dilaksanakan oleh Badan Pertanahan Nasional/Menteri Negara Agraria. Setelah 39 tahun berlakunya UUPA, diundangkan Undang-undang No. 22 Tahun 1999 tentang Pemerintahan Daerah, yang di dalamnya mengatur otonomi daerah. Dengan diundangkannya Undang-undang No. 22 Tahun 1999 terjadi perubahan hubungan antara Pemerintah Pusat dengan Pemerintah Daerah, yaitu semua bidang kegiatan pembangunan yang semula sifatnya terpusat pada Pemerintah Pusat, kemudian ada beberapa bidang kegiatan pembangunan yang didesentralisasikan oleh Pemerintah Pusat kepada Pemerintah Daerah. Bidang kegiatan pembangunan yang didesentralisasikan oleh Pemerintah Pusat kepada Pemerintah Daerah, antara lain adalah pertanahan. Undang-undang No. 22 Tahun 1999 dinyatakan tidak berlaku lagi oleh Undang-undang No. 32 Tahun 2004 tentang Pemerintahan Daerah. Dalam Undang-undang No. 32 Tahun 2004 ditegaskan bahwa ada beberapa bidang kegiatan pembangunan yang 
didesentralisasikan oleh Pemerintah Pusat kepada Pemerintah Daerah, salah satunya adalah pelayanan pertanahan.

Dengan berlakunya Undang-undang No. 32 Tahun 2004 terjadi konflik norma dengan UUPA. UUPA menegaskan bahwa kewenangan di bidang pertanahan sifatnya terpusat pada Pemerintah Pusat, sedangkan Undang-undang No. 32 Tahun 2004 menegaskan bahwa kewenangan di bidang pelayanan pertanahan sifatnya desentralistik dari Pemerintah Pusat kepada Pemerintah Daerah.

Permasalahan yang hendak diteliti dalam tulisan ini dapat dirumuskan apakah kewenangan Pemerintah Kabupaten/Kota di bidang pertanahan bersifat otonom?

\section{METODE PENELITIAN}

Metode yang digunakan adalah metode penelitian hukum, khususnya penelitian hukum normatif. Penelitian hukum normatif merupakan penelitian yang mengkaji suatu masalah berdasarkan peraturan perundang-undangan yang berlaku, khususnya peraturan perundang-undangan di bidang pertanahan. Pendekatan masalah yang dipergunakan adalah pendakatan peraturan perundangundangan (statute approach) dan pendekatan konseptual (conceptual approach).

\section{PEMBAHASAN}

\section{PENGATURAN KEWENANGAN DI BIDANG PERTANAHAN}

Suatu badan hukum, yaitu Perseroan Terbatas (PT), Perusahaan Perseroan, Perusahaan Umum, Departemen, Lembaga Pemerintah Non Departemen, yayasan, termasuk Pemerintah Provinsi, Pemerintah Kabupaten/Kota dibentuk tentu ada maksud dan tujuannya. Juga ada kewajiban, hak, tugas dan kewenangannya. Kewenangan yang melekat pada badan hukum tersebut ada yang bersifat internal dan eksternal.

Philipus M Hadjon mengemukakan pendapat tentang pengertian kewenangan, yaitu : 
"Istilah wewenang atau kewenangan sering dijabarkan dengan istilah bevoegdheid dalam istilah Hukum Belanda. Kalau dilakukan pengkajian secara cermat, ada perbedaan antara istilah wewenang atau kewenangan dengan istilah bevoegdheid. Perbedaan dalam karakter hukumnya, istilah bevoegdheid digunakan baik dalam konsep hukum privat maupun dalam konsep huku publik. Sedangkan dalam konsep Hukum Indonesia, istilah wewenang atau kewenangan digunakan dalam konsep hukum publik. Dalam Hukum Tata Negara, wewenang (bevoegdheid) dideskripsikan sebagai kekuasaan hukum (rechtsmacht). Jadi, dalam konsep hukum publik, wewenang berkaitan dengan kekuasaan. Oleh karena itu, konsep wewenang merupakan konsep dalam hukum publik. ${ }^{1}$

Wewenang nengandung arti kemampuan untuk melakukan suatu tindakan hukum publik. Atau dengan perkataan lain, wewenang adalah kemampuan bertindak yang diberikan oleh Undang-undang yang berlaku untuk melakukan hubungan dan perbuatan hukum. ${ }^{2}$ Wewenang merupakan bagian yang sangat penting dalam Hukum Administrasi, karena pemeirntahan baru dapat melakukan fungsinya atas dasar wewenang yang diperoleh. Keabsahan tindakan pemerintahan diukur berdasarkan wewenang yang diatur dalam peraturan perundang-undangan (legaliteit beginselen). Suatu kewenangan harus didasarkan pada ketentuan hukum yang berlaku, sehingga bersifat sah. ${ }^{3}$

Hak untuk mengatur dari Negara atau Pemerintah disebut sebagai wewenang atau kewenangan atau bevoegdheid. Wewenang atau kewenangan tersebut haruslah sah atau rechtmatig yang memiliki tiga fungsi, yaitu :

1. Bagi aparat pemerintahan, asas keabsahan berfungsi sebagai norma pemerintahan (bestuurnormen).

2. Bagi masyarakat, asas keabsahan berfungsi sebagai alas an mengajukan gugatan terhadap tindak pemerintahan (beroepsgronden).

3. Bagi hakim, asas keabsahan berfungsi sebagai dasar pengujian suatu tindak pemerintahan (toetsingsgronden). ${ }^{4}$

Khusus kewenangan di bidang pertanahan diatur dalam Undang-undang No. 5 Tahun 1960 tentang Peraturan Dasar Pokok-pokok Agraria, atau yang lebih

\footnotetext{
${ }^{1}$ Philipus M Hadjon, Pengantar Hukum Administrasi di Indonesia, Gadjah Mada University Press, Yogyakarta, 2005, h. 105.

${ }_{2}^{2}$ S.F. Marbun, Peradilan Administrasi Negara dan Upaya Administratif di Indonesia, Liberty, Yogyakarta, 1997, h. 154.

${ }^{3}$ Suriansyah Murhani, Kewenangan Pemerintah Dalam Mengurus Bidang Pertanahan, Laksbang Justitia, Surabaya, 2009, h. 14.

${ }^{4}$ Ibid., h. 30.
} 
dikenal dengan sebutan Undang-undang Pokok Agraria (UUPA). Kewenangan di bidang pertanahan oleh Negara diatur dalam Pasal 2 ayat (1) UUPA, yaitu Negara sebagai organisasi kekuasaan seluruh rakyat menguasai bumi, air, ruang angkasa, dan kekayaan alam yang terkandung di dalamnya. Kewenangan Negara atas tanah yang disebut hak menguasai Negara atas tanah, wewenangnya dimuat dalam Pasal 2 ayat (2) UUPA, yaitu :

a. Mengatur dan menyelenggarakan peruntukan, penggunaan, persediaan, dan pemeliharaan bumi, air, dan ruang angkasa;

b. Menentukan dan mengatur hubungan-hubungan hukum antara orang-orang dengan bumi, air, dan ruang angkasa;

c. Menentukan dan mengatur hubungan-hubungan hukum antara orang-orang dan perbuatan-perbuatan hukum yang mengenai bumi, air, dan ruang angkasa.

Pasal 2 UUPA mengatur kewenangan atas tanah yang dilaksanakan oleh Negara sebagai organisasi kekuasaan seluruh rakyat, yang lebih dikenal dengan sebutan hak menguasai negara atas tanah. Hak menguasai negara atas tanah merupakan pelaksanaan dari hak bangsa Indonesia atas tanah. Hak menguasai Negara atas tanah bersifat publik, yaitu mengatur dan menentukan, sedangkan hak bangsa Indonesia atas tanah bersifat privat dan publik. Pasal 2 ayat (2) UUPA memuat 3 (tiga) macam wewenang hak menguasai negara atas tanah. Berdasarkan ketentuan Pasal 2 UUPA menunjukkan bahwa urusan pertanahan dikonsepsikan dilaksanakan secara sentralistis atau merupakan tugas Pemerintah Pusat. Namun demikian, dalam Pasal 2 ayat (4) UUPA ditegaskan bahwa hak menguasai dari Negara tersebut di atas pelaksanaannya dapat dikuasakan kepada Daerah-daerah Swatantra dan masyarakat-masyarakat hukum adat, sekedar diperlukan dan tidak bertentangan dengan kepentingan nasional, menurut ketentuan-ketentuan Peraturan Pemerintah. Berdasarkan ketentuan Pasal 2 ayat (4) UUPA, hak menguasai Negara atas tanah dalam pelaksanaannya dapat dilimpahkan kewenangannya kepada Pemerintah Daerah yang akan diatur dengan Peraturan Pemerintah. 
Ketentuan yang menunjukkan bahwa kewenangan di bidang pertanahan bersifat sentralistis, yaitu dalam Penjelasan Pasal 2 UUPA, yang isinya :

"Ketentuan dalam ayat (4) adalah bersangkutan dengan asas otonomo dan medebewind dalam penyelenggaraan pemerintahan daerah. Soal agraria menurut sifatnya dan pada asasnya merupakan tugas Pemerintah Pusat (Pasal 33 ayat (3) Undang-undang Dasar). Dengan demikian, maka pelimpahan wewenang untuk melaksanakan hak penguasaan dari Negara atas tanah itu adalah merupakan medebewind. Segala sesuatunya akan diselenggarakan menurut keperluan dan sudah barang tentu tidak boleh bertentangan dengan kepentingan nasional. Wewenang dalam bidang agraria dapat merupakan sumber keuangan bagi daerah itu"

Dalam pelaksanaan hak menguasai negara atas tanah, Pemerintah Pusat dapat menguasakan (memberi kuasa) kepada Pemerintah Daerah, namun hal itu bukan merupakan suatu keharusan. Kata-kata "dapat dikuasakan" dan "sekedar diperlukan" memberi tekanan bahwa pemberian kuasa kepada Pemerintah Daerah bukan suatu keharusan. ${ }^{5}$ Berdasarkan ketentuan Pasal 2 ayat (4) UUPA, tidak ada suatu keharusan atau kewajiban bagi Pemerintah Pusat untuk melimpahkan kewenangan atas tanah kepada Pemerintah Daerah. Kalau pun ada pelimpahan kewenangan di bidang pertanahan oleh Pemerintah Pusat kepada Pemerintah Daerah sifatnya sekedar diperlukan. Pelimpahan kewenangan itu pun tidak boleh bertentangan dengan kepentingan nasional dan akan diatur dengan Peraturan Pemerintah.

Boedi Harsono memberikan pendapat mengenai pelaksanaan tugas agraria, yaitu asas soal agraria merupakan tugas Pemerintah Pusat. Asas ini sangat penting untuk mempertahankan dan melestarikan persatuan dan kesatuan bangsa, dan wilayah nasional Indonesia. oleh karena itu, tugas kewenangan di bidang agraria/pertanahan tidak boleh diotonomkan kepada daerah dan harus tetap ada pada Pemerintah Pusat. Pelimpahan sebagian wewenang tersebut kepada daerah dapat dilakukan dalam bentuk "medebewind". 6

Yang dimaksud dengan medebewind atau tugas pembantuan menurut Pasal 1 angka 9 Undang-undang No. 32 Tahun 2004 tentang Pemerintahan Daerah,

\footnotetext{
${ }^{5}$ Nur Hasan Ismail, "Otonomi Bidang Pertanahan : Reposisi Peranan Pusat dan Daerah, dan Ideologi Politik Pertanahan”, Makalah, Fakultas Hukum Universitas Gadjah Mada, Yogyakarta, 2000, h. 34.

${ }^{6}$ Boedi Harsono, Hukum Agraria Indonesia Sejarah Pembentukan Undang-undang Pokok Agraria, Isi, dan Pelaksanaannya, Djambatan, Jakarta, 2003, h. 245.
} 
adalah penugasan dari Pemerintah kepada daerah dan/atau desa, dari Pemerintah Provinsi kepada kabupaten/kota dan/aau desa serta dari Pemerintah Kabupaten/Kota kepada desa untuk melaksanakan tugas tertentu. Pengertian yang lebih lengkap tentang tugas pembantuan disebutkan dalam Pasal 1 huruf 2 Peraturan Pemerintah No. 52 Tahun 2001 tentang Penyelenggaraan Tugas Pembantuan, yaitu penugasan dari Pemerintah kepada daerah dan desa, dan dari daerah kepada desa untuk melaksanakan tugas tertentu yang disertai pembiayaan, sarana dan prasarana serta sumber daya manusia dengan kewajiban melaporkan pelaksanaannya dan mempertanggungjawabkannya kepada yang menugaskan.

Pelaksanaan kewenangan di bidang pertanahan terjadi perubahan sejak diundangkan Undang-undang No. 22 Tahun 1999 tentang Pemerintahan Daerah, yang di dalamnya mengatur otonomi daerah, mengubah kebijakan kewenangan pengurusan bidang pertanahan yang sebelumnya bersifat sentralistik diubah menjadi desentralistik. Otonomi daerah menghendaki adanya penyerahan kewenangan dari Pemerintah Pusat kepada Pemerintah Daerah dengan pengertian bahwa kewenangan tersebut merupakan kepunyaan Pemerintah Daerah. Kewenangan Pemerintah Pusat yang sebelumnya mencakup semua sektor pembangunan telah dikurangi menjadi hanya beberapa sektor strategis.

Kehadiran Undang-undang No. 22 Tahun 1999 ini telah mendatangkan kejutan-kejutan terutama di bidang dan urusan pemerintahan dengan kewenangan yang sentralistik, termasuk dalam kelompok ini adalah bidang pertanahan. Kewenangan dari hak menguasai dari Negara atas tanah menurut UUPA harus dilaksanakan secara sentralistik oleh Pemerintah Pusat. Namun, dengan Undangundang No. 22 Tahun 1999, kewenangan tersebut diserahkan kepada Pemerintah Daerah Kabupaten atau Kota sebagai kewenangan otonomi daerah. ${ }^{7}$ Pasal 7 ayat (1) Undang-undang No. 22 Tahun 1999 menetapkan 11 (sebelas) bidang pembangunan yang diserahkan kewenangannya oleh Pemerintah Pusat kepada Pemerintah Kabupaten/Kota, yaitu pekerjaan umum, kesehatan, pendidikan dan kebudayaan, pertanian, perhubungan, industri dan perdagangan, penanaman modal, lingkungan hidup, pertanahan, koperasi, dan tenaga kerja.

\footnotetext{
${ }^{7}$ Ibid, h. 38 .
} 
Undang-undang No. 22 Tahun 1999 dinyatakan tidak berlaku lagi oleh Undang-undang No. 32 Tahun 2004 tentang Pemerintahan Daerah. Dalam Pasal 14 ayat (1) Undang-undang No. 32 Tahun 2004 dinyatakan bahwa ada 16 (enambelas) urusan wajib yang menjadi kewenangan Pemerintah Daerah Kabupaten/Kota. Salah satu dari urusan wajib tersebut adalah pelayanan pertanahan. Untuk melaksanakan ketentuan Pasal 14 ayat (3) Undang-undang No. 32 Tahun 2004 dibentuklah Peraturan Pemerintah No. 38 Tahun 2007 tentang Pembagian Urusan Pemerintahan Antara Pemerintah, Pemerintah Daerah Provinsi, dan Pemerintah Daerah Kabupaten/Kota.

Di era otonomi daerah yang ditandai dengan diundangkannya Undangundang No. 22 Tahun 1999, yang dinyatakan tidak berlaku lagi Undang-undang No. 32 Tahun 2004 terjadi perubahan kewenangan di bidang pertanahan yang semula menurut UUPA bersifat sentralistik diubah menjadi bersifat desentralistik. Pemerintah Kabupaten/Kota diberikan kewenangan untuk mengurusi bidang pertanahan, termasuk pelayanan pertanahan.

\section{SIFAT KEWENANGAN PEMERINTAH KABUPATEN/KOTA DI BIDANG PERTANAHAN.}

Negara sebagai organisasi kekuasaan seluruh rakyat pada tingkatan tertinggi menguasai bumi, air, dan ruang angkasa, termasuk kekayaan alam yang terkandung di dalamnya. Hak menguasai Negara atas bumi, air, dan ruang angkasa berisi wewenang yang ditetapkan dalam Pasal 2 ayat (2) UUPA, yaitu :

a. mengatur dan menyelenggarakan peruntukan, penggunaan, persediaan, dan pemeliharaan bumi, air, dan ruang angkasa;

b. menentukan dan mengatur hubungan-hubungan hukum antara orang-orang dengan bumi, air, dan ruang angkasa;

c. menentukan dan mengatur hubungan-hubungan hukum antara orang-orang dan perbuatan-perbuatan hukum yang mengenai bumi, air, dan ruang angkasa. 
Wewenang Negara atas bumi, air, dan ruang angkasa, termasuk kekayaan alam yang terkandung di dalamnya merupakan tugas Pemerintah Pusat. Namun demikian, wewenang ini dalam pelaksanaannya dapat dilimpahkan kepada Pemerintah Daerah sebagaimana ditetapkan dalam Pasal 2 ayat (4) UUPA, yaitu : "Hak menguasai dari Negara tersebut di atas pelaksanaannya dapat dikuasakan kepada Daerah-daerah Swatantra dan masyarakat-masyarakat hukum adat, sekadar diperlukan dan tidak bertentangan dengan kepentingan nasional, menurut ketentuan-ketentuan Peraturan Pemerintah“.

Urusan agraria yang meliputi bumi, air, dan ruang angkasa termasuk kekayaan alam yang terkandung di dalamnya dikonsepsikan dalam UUPA dilaksanakan secara sentralistik atau merupakan tugas Pemerintah Pusat. Namun demikian, tugas Pemerintah Pusat dapat dilimpahkan kekuasaannya kepada Daerah Swatantra (Pemerintah Daerah). Ketentuan tentang urusan agraria merupakan tugas Pemerintah Pusat dan adanya pelimpahan kewenangan kepada Daerah Swatantra (Pemerintah Daerah) ditetapkan dalam Penjelasan Pasal 2 UUPA, yaitu : "Ketentuan dalam ayat (4) adanya bersangkutan dengan asas otonomi dan medebewind dalam rangka penyelenggaraan pemerintahan daerah. Soal agraria menurut sifatnya dan pada asasnya merupakan tugas Pemerintah Pusat (Pasal 33 ayat (3) Undang-undang Dasar). Dengan demikian, maka pelimpahan wewenang untuk melaksanakan hak penguasaan dari Negara atas tanah itu adalah merupakan medebewind. Segala sesuatunya akan diselenggarakan menurut keperluan dan sudah barang tentu tidak boleh bertentangan dengan kepentingan nasional. Wewenang dalam bidang agraria dapat merupakan sumber keuangan bagi daerah itu".

Urusan agraria sejak berlakunya Undang-undang No. 5 Tahun 1960 (Undang-undang Pokok Agraria) pada mulanya dilaksanakan oleh Menteri Agraria, kemudian oleh Menteri Agraria dan Pertanian, lalu oleh Direktorat Jenderal Agraria di bawah Departemen Dalam Negeri. Sejak tahun 1988, urusan pertanahan dilaksanakan oleh Badan Pertanahan Nasional melalui Keputusan Presiden No. 26 Tahun 1988 tentang Badan Pertanahan Nasional. Menurut Pasal 1 ayat (1) Keputusan Presiden No. 26 Tahun 1988, Badan Pertanahan Nasional 
adalah Lembaga Pemerintah Non Departemen yang berkedudukan di bawah dan bertanggung jawab langsung kepada Presiden. Badan Pertanahan Nasiona dibentuk dengan maksud menggantikan tugas Direktorat Jenderal Agraria Departemen Dalam Negeri.

Keputusan Presiden No. 26 Tahun 1988 diubah oleh Keputusan Presiden No. 154 Tahun 1999 tentang Perubahan Atas Keputusan Presiden No. 26 Tahun 1988 tentang Badan Pertanahan Nasional. Keputusan Presiden No. 26 Tahun 1988 yang diubah oleh Keputusan Presiden No. 154 Tahun 1999 dinyatakan tidak berlaku lagi oleh Keputusan Presiden No. 95 Tahun 2000 tentang Badan Pertanahan Nasional. Pengertian Badan Pertanahan Nasional menurut Pasal 1 ayat (1) Keputusan Presiden No. 95 Tahun 2000 sama dengan Pasal 1 ayat (1) Keputusan Presiden No. 26 Tahun 1988. Perbedaan struktur pemimpin Badan Pertanahan Nasional antara Keputusan Presiden No. 26 Tahun 1988 dengan Keputusan Presiden No. 95 Tahun 2000, adalah pada Keputusan Presiden No. 26 Tahun 1988 ditetapkan bahwa Badan Pertanahan Nasional dipimpin oleh seorang kepala tanpa dibantu oleh wakil kepala, sedangkan dalam Keputusan Presiden No. 95 Tahun 2000 ditetapkan bahwa Badan Pertanahan Nasional dipimpin oleh seorang kepala diantu oleh seorang wakil kepala.

Pada saat ini, Badan Pertanahan Nasional diatur dalam Peraturan Presiden No. 10 Tahun 2006 tentang Badan Pertanahan Nasional. Badan Pertanahan Nasional adalah Lembaga Pemerintah Non Departemen yang berada di bawah dan bertanggung jawab kepada Presiden. Badan Pertanahan Nasional dipimpin oleh Kepala. Badan Pertanahan Nasional mempunyai tugas melaksaakan tugas pemerintahan di bidang pertanahan secara nasional, regional, dan sektoral.

Sebelum diundangkan Undang-undang No. 22 Tahun 1999 tentang Pemerintahan Daerah, kewenangan pengurusan bidang pertanahan ada pada Pemerintah Pusat yang bersifat sentralistik, sedangkan kewenangan Pemerintah Daerah melaksanakan kewenangan pengurusan bidang pertanahan berdasarkan pelimpahan kewenangan yang bersifat medebewind. Penyerahan kewenangan pengurusan bidang pertanahan kepada Pemerintah Daerah dibatasi hanya menyangkut kewenangan menyelenggarakan atau melaksanakan dan bukan 
kewenangan untuk mengatur. Penyerahan kewenangan itupun didasarkan asumsi bahwa instansi di daerah yang melaksanakan kewenangan tersebut merupakan instansi Pemeirntah Pusat yang ada di daerah dan bukan sebagai lembaga otonom daerah.

Dengan diundangkan Undang-undang No. 22 Tahun 1999, yang di dalamnya mengatur otonomi daerah, mengubah kebijakan kewenangan pengurusan bidang pertanahan, yaitu yang sebelumnya bersifat sentralistik diubah menjadi desentralistik. Otonomi daerah menghendaki adanya penyerahan kewenangan dari Pemerintah Pusat kepada Pemerintah Daerah dengan pengertian bahwa kewenangan tersebut merupakan kepunyaan Pemerintah Daerah. Kebijakan otonomi daerah ditandai oleh lahirnya Undang-undang No. 22 Tahun 1999, yang mengubah hubungan antara Pemerintah Pusat dengan Pemerintah Daerah, yang sebelumnya bersifat sentralistik diubah menjadi desentralistik. Kewenangan Pemerintah Pusat yang sebelumnya mencakup semua sektor pembangunan telah dikurangi menjadi hanya beberapa sektor strategis.

Sektor-sektor pembangunan yang kewenangannya masih dipegang oleh Pemerintah Pusat ditetapkan dalam Pasal 7 Undang-undang No. 22 Tahun 1999, yaitu :

(1) kewenangan daerah mencakup kewenangan dalam seluruh bidang pemerintahan, kecuali kewenangan dalam bidang politik luar negeri, pertahanan keamanan, peradilan, moneter dan fiskal, agama serta kewenangan bidang lain.

(2) Kewenangan bidang lain, sebagaimana dimaksud pada ayat (1), meliputi kebijakan tentang perencanaan nasional dan pengendalian pembangunan nasional secara makro, dana perimbangan keuangan,, sistem administrasi negara dna lembaga perekonomian negara, pembinaan dan pemberdayaan sumber daya manusia, pemberdayaan sumber daya alam serta teknologi tinggi yang srategis, konservasi, dan standardisasi nasional.

Tidak semua bidang pembangunan yang diserahkan kewenangannya oleh Pemerintah Pusat kepada Pemerintah Daerah. Bidang pembangunan yang tidak 
diserahkan kewenangannya oleh Pemerintah Pusat kepada Pemerintah Daerah, adalah bidang politik luar negeri, pertahanan keamanan, peradilan, moneter dan fiskal, agama serta kewenangan bidang lain. Kewenangan bidang lain, meliputi kebijakan tentang perencanaan nasional dan pengendalian pembangunan nasional secara makro, dana perimbangan keuangan,, sistem administrasi negara dna lembaga perekonomian negara, pembinaan dan pemberdayaan sumber daya manusia, pemberdayaan sumber daya alam serta teknologi tinggi yang srategis, konservasi, dan standardisasi nasional.

Bidang pembangunan yang kewenangannya diserahkan oleh Pemerintah Pusat kepada Pemerintah Kabupaten/Kota ditetapkan dalam Pasal 11 Undangundang No. 22 Tahun 1999, yaitu :

(1) Kewenangan daerah kabupaten/kota mencakup semua kewenangan pemerintahan, selain kewenangan yang dikecualikan dalam Pasal 7 dan yang diatur dalam Pasal 9.

(2) Bidang pemerintahan yang wajib dilaksanakan oleh daerah kabupaten dan daerah kota, meliputi pekerjaan umum, kesehatan, pendidikan dan kebudayaan, pertanian, perhubungan, industri dan perdagangan, penanaman modal, lingkungan hidup, pertanahan, koperasi dan tenaga kerja.

Undang-undang No. 22 Tahun 199 menetapkan 11 (sebelas) bidang pembangunan yang diserahkan oleh Pemerintah Pusat kepada Pemerintah Kabupaten/Kota, yaitu pekerjaan umum, kesehatan, pendidikan dan kebudayaan, pertanian, perhubungan, industri dan perdagangan, penanaman modal, lingkungan hidup, pertanahan, koperasi dan tenaga kerja.

Undang-undang No. 22 Tahun 1999 dilaksanakan oleh Peraturan Pemerintah No. 25 Tahun 2000 tentang Kewenangan Pemerintah dan Kewenangan Provinsi Sebagai Daerah Otonom. Dalam bidang pertanahan, penjabaran kewenangan pelayanan pertanahan dirumuskan dalam Pasal 2 ayat (3) angka 14, meliputi bidang kegiatan sebagai berikut :

a. Penetapan persyaratan pemberian hak-hak atas tanah;

b. Penetapan persyaratan landreform; 
c. Penetapan standar administrasi pertanahan;

d. Pedoman biaya pelayanan pertanahan;

e. Penetapan kerangka kadastral nasional dan pelaksanaan pengukuran kerangka dasar kadastral nasional Orde I dan Orde II.

Pada tanggal 17 Januari 2001, Presiden menerbitkan Keputusan Presiden No. 10 Tahun 2001 tentang Pelaksanaan Otonomi Daerah di Bidang Pertanahan, yang menyatakan bahwa pelaksanaan otonomi daerah di bidang pertanahan sepenuhnya masih mengacu pada Peraturan, Keputusan, Instruksi, dan Surat Edaran Menteri Negara Agraria/Kepala Badan Pertanahan Nasional (BPN) yang telah ada. Pasal 1 Keputusan Presiden No. 10 Tahun 2001 menyatakan bahwa : "Sebelum ditetapkan peraturan yang baru berdasarkan Peraturan Pemerintah No. 25 Tahun 2000 tentang Kewenangan Pemerintah dan Kewenangan Provinsi Sebagai Daerah Otonom, pelaksanaan otonomi daerah di bidang pertanahan berlaku Peraturan, Keputusan, Instruksi, dan Surat Edaran Menteri Negara Agraria/Kepala Badan Pertanahan Nasional yang telah ada".

Selanjutnya Pemerintah Pusat menerbitkan Keputusan Presiden No. 62 Tahun 2001 tentang Perubahan Atas Keputusan Presiden Nomor 166 Tahun 2000 tentang Kedudukan, Tugas, Fungsi, Kewenangan, Susunan Organisasi, dan Tata Kerja Lembaga Pemerintah Non Departemen Sebagaimana Telah Diubah Terakhir Dengan Keputusan Presiden Nomor 42 Tahun 2001, Pasal I (109) Keputusan Presiden No. 62 Tahun 2001 menyatakan bahwa : "Sebagian tugas pemerintahan yang dilaksanakan Badan Pertanahan Nasional di daerah tetap dilaksanakan oleh Pemerintah Pusat sampai dengan ditetapkannya seluruh peraturan perundang-undangan di bidang pertanahan, selambat-lambatnya 2 (dua) tahun".

Menindaklanjuti Keputusan Presiden No. 62 Tahun 2001, Menteri Dalam Negeri menerbitkan Surat Edaran Menteri Dalam Negeri No.. 593.08/381/UMPEM, perihal pelaksanaan otonomi bidang pertanahan tanggal 30 Juli 2001, bahwa paling lambat bulan Mei 2003 seluruh kewenangan sebagaimana tersurat dalam Peraturan Pemerintah No. 25 Tahun 2000 harus sudah 
diserahkan kepada Pemerintah Daerah. Pada kenyataannya tidak terjadi penyerahan kewenangan bidang pertanahan dari Pemerintah Pusat kepada Pemerintah Daerah.

Dalam rangka pelaksanaan Ketetapan MPR RI No. IX/MPR/2001 tentang Pembaruan Agraria dan Pengelolaan Sumber Daya Alam dan dengan dasar bahwa seluruh wilayah Republik Indonesia adalah kesatuan tanah air dari seluruh rakyat Indonesia, yang bersatu sebagai Bangsa Indonesia, dalam keranghka Negara Kesatuan Republik Indonesia diterbitkan Keputusan Presiden No. 34 Tahun 2003 tentang Kebijakan Nasional di Bidang Pertanahan. Dalam Keputusan Presiden No. 34 Tahun 2003 ditetapkan bahwa : "Dalam rangka mewujudkan konsepsi, kebijakan, dan sistem pertanahan nasional yang utuh dan terpadu, dan pelaksanaan Ketetapan MPR RI No. IX/MPR/2001, Badan Pertanahan Nasional melakukan langkah-langlah percepatan, yaitu penyusunan Rancangan Undangundang tentang Penyempurnaan Undang-undang Nomor 5 Tahun 1960 tentang Peraturan Dasar Pokok-pokok Agraria, dan Rancangan Undang-undang tentang Hak Atas Tanah serta peraturan perundang-undangan lainnya di bidang pertanahan.

Keputusan Presiden No. 34 Tahun 2003 menetapkan 9 (sembilan) kewenangan Pemerintah di bidang pertanahan yang dilaksanakan oleh Pemerintah Kabupaten/Kota, yaitu :

a. Pemberian izin lokasi;

b. Penyelenggaraan pengadaan tanah untuk kepentingan pembangunan;

c. Penyelesaian sengketa tanah garapan;

d. Penyelesaian masalah ganti kerugian dan santunan tanah untuk pembangunan;

e. Penetapan subyek dan obyek redistribusi tanah, serta ganti kerugian kelebihan tanah maksimum dan tanah absentee;

f. Penetepan dan penyelesaian masalah tanah ulayat;

g. Pemanfaatan dan penyelesaian masalah tanah kosong;

h. Pemberian izin membuka tanah;

i. Perencanaan penggunaan tanah wilayah kabupaten/kota. 
Dalam rangka pelaksanaan 9 (sembilan) kewenangan Pemerintah di bidang pertanahan di daerah, Badan Pertanahan Nasional diberi waktu 3 (tiga) bulan sejak diterbitkannya Keputusan Presiden No. 34 Tahun 2003 untuk menyusun norma-norma dan/atau standardisasi mekanisme ketatalaksanaan, kualitas produk dan kualifikasi sumber daya manusia yang diperlukan. Keputusan Presiden No. 34 Tahun 2003 dirasakan oleh Pemerintah Kabupaten/Kota mempersempit kewenangan pelayanan pertanahan yang sebelumnya sudah diatur dalam Keputusan Menteri Dalam Negeri dan Otonomi Daerah No. 50 Tahun 2000 tentang Pedoman Susunan Organisasi dan Tata Kerja Perangkat Daerah Kabupaten/Kota yang mencantmkan ketentuan tentang Kewenangan Dinas Pertanahan Kabupaten/Kota, yang meliputi :

1. Penyelenggaraan tata guna tanah dan tata ruang;

2. Penyelenggaraan pengaturan dan penguasaan tanah;

3. Penyelenggaraa pengaturan dan pengurusan hak-hak atas tanah;

4. Penyelenggaraan pengukuran dan pendaftaran tanah;

5. Penyelenggaraan administrasi pertanahan;

6. Penetapan kerangka dasar kadastral daerah dan pelaksanaan pengukuran kerangka dasar kadastral daerah; dan

7. Penanganan penyelesaian masalah dan sengketa pertanahan serta peningkatan partisipasi masyarakat.

Undang-undang No. 22 Tahun 1999 dinyatakan tidak berlaku lagi oleh Undang-undang No. 32 Tahun 2004 tentang Pemerintahan Daerah, yang menetapkan bahwa :

1. Pemerintah Daerah menyelenggarakan urusan pemerintahan yang menjadi kewenangannya, kecuali urusan pemerintahan yang oleh Undang-undang ini ditentukan menjadi urusan Pemerintah;

2. Dalam menyelenggarakan urusan pemerintahan yang menjadi kewenanangan daerah, Pemerintah Daerah menjalankan otonomi seluas-luasnya untuk mengatur dan mengurus sendiri urusan pemerintahan berdasarkan asas otonomi dan tugas pembantuan; 
3. Urusan pemerintahan yang menjadi urusan Pemerintah, yaitu :
a. politik luar negeri;
b. pertahananan;
c. keamanan;
d. yustisi;
e. moneter dan fiskal nasional; dan
f. agama.

Urusan wajib yang menjadi kewenangan Pemerintah Daerah Provinsi ditetapkan dalam Pasal 13 ayat (1) Undang-undang No. 32 Tahun 2004, yaitu:

a. perencanaan dan pengendalian pembangunan;

b. perencanaan, pemanfaatan, dan pengawasan tata ruang;

c. penyelenggaraan ketertiban umum dan ketentraman masyarakat;

d. penyediaan sarana dan prasarana umum;

e. penanganan bidang kesehatan;

f. penyelenggaraan pendidikan dan alokasi sumber daya manusia potensial;

g. penanggulangan masalah sosial lintas kabupaten/kota;

h. pelayanan bidang ketenagakerjaan lintas kabupaten/kota;

i. fasilitas pengembangan koperasi, usaha kecil, dan menengah termasuk lintas kabupaten/kota;

j. pengendalian lingkungan hidup;

k. pelayanan pertanahan termasuk lintas kabupaten/kota;

1. pelayanan kependudukan dan catatan sipil;

m. pelayanan administrasi umum pemerintahan;

n. pelayanan administrasi penanaman modal termasuk lintas kabupaten/kota;

o. penyelenggaraan pelayanan dasar lainnya yang belum dapat dilaksanakan oleh kabupaten/kota;

p. urusan wajib lainnya yang diamanatkan oleh peraturan perundang-undangan. 
Urusan wajib yang menjadi kewenangan Pemerintah Daerah Kabupaten/Kota ditetapkan dalam Pasal 14 ayat (1) Undang-undang No. 32 Tahun 2004, yaitu :

a. perencanaan dan pengendalian pembangunan;

b. perencanaan, pemanfaatan, dan pengawasan tata ruang;

c. penyelenggaraan ketertiban umum dan ketentraman masyarakat;

d. penyediaan sarana dan prasarana umum;

e. penanganan bidang kesehatan;

f. penyelenggaraan pendidikan;

g. penanggulangan masalah sosial;

h. pelayanan bidang ketenagakerjaan;

i. fasilitas pengembangan koperasi, usaha kecil, dan menengah;

j. pengendalian lingkungan hidup;

k. pelayanan pertanahan;

1. pelayanan kependudukan dan catatan sipil;

m. pelayanan administrasi umum pemerintahan;

n. pelayanan administrasi penanaman modal;

o. penyelenggaraan pelayanan dasar lainnya;

p. urusan wajib lainnya yang diamanatkan oleh peraturan perundang-undangan.

Untuk melaksanakan ketentuan Pasal 14 ayat (3) Undang-undang No. 32 Tahun 2004 dibentuklah Peraturan Pemerintah No. 38 Tahun 2007 tentang Pembagian Urusan Pemerintahan Antara Pemerintah, Pemerintah Daerah Provinsi, dan Pemerintah Daerah Kabupaten/Kota. Dalam Pasal 7 ayat (2) nya ditetapkan bahwa urusan wajib pemerintahan yang wajib diselenggarakan oleh pemerintahan daerah provinsi dan pemerintahan daerah kabupaten/kota berkaitan dengan pelayanan dasar, meliputi :
a. pendidikan;
b. kesehatan;
c. lingkungan hidup;
d. pekerjaan umum; 
e. penataan ruang;

f. perencanaan pembangunan;

g. perumahan;

h. kepemudaan dan olahraga;

i. penanaman modal;

j. koperasi, usaha kecil dan menengah;

k. kependudukan dan catatan sipil;

1. ketenagakerjaan;

m. ketahanan pangan;

n. pemberdayaan perempuan dan perlindungan anak;

o. keluarga berencana dan keluarga sejahtera;

p. perhubungan;

q. komunikasi dan informatika;

r. pertanahan;

s. kesatuan bangsa dan politik dalam negeri;

t. otonomi daerah, pemerintahan umum, administrasi keuangan daerah, perangkat daerah, kepegawaian, dan persandian;

u. pemberdayaan masyarakat dan desa;

v. sosial;

w. kebudayaan;

x. statistik;

y. kearsipan;

z. perpustakaan.

Khusus urusan wajib pemerintahan bidang pertanahan, kegiatannya dijabarkan dalam Lampiran Peraturan Pemerintah Nomor 38 Tahun 2007, yaitu :

1. Pemberian izin lokasi;

2. Penyelenggaraan pengadaan tanah untuk kepentingan pembangunan;

3. Penyelesaian sengketa tanah garapan;

4. Penyelesaian masalah ganti kerugian dan santunan tanah untuk pembangunan; 
5. Penetapan subyek dan obyek redistribusi tanah, serta ganti kerugian kelebihan tanah maksimum dan tanah absentee;

6. Penetepan dan penyelesaian masalah tanah ulayat;

7. Pemanfaatan dan penyelesaian masalah tanah kosong;

8. Pemberian izin membuka tanah;

9. Perencanaan penggunaan tanah wilayah kabupaten/kota

Urusan bidang agraria yang meliputi bumi, air, dan ruang angkasa, termasuk kekayaan alam yang terkandung di dalamnya dikonsepsikan oleh UUPA dilaksanakan secara sentralistik atau merupakan tugas Pemerintah Pusat. Kekuasaan Negara atas bumi, air, dan ruang angkasa, termasuk kekayaan alam yang terkandung di dalamnya, atau yang secara teknis yuridis disebut hak menguasai Negara diserahkan pelaksanaannya kepada Pemerintah Pusat. Dalam UUPA sendiri memang tidak ditemukan kata atau kalimat yang menyatakan demikian, namun dari ketentuan Pasal 2 ayat (4) UUPA beserta Penjelasannya secara penafsiran a contrario dengan jelas dapat disimpulkan bahwa adanya sentralisme pelaksanaan hak menguasai negara. Dengan mencermati isi Pasal 2 ayat (4) UUPA dan Penjelasannya tersebut, kewenangan hak menguasai negara dilaksanakan oleh Pemerintah Pusat secara sentralistik. Hal ini jelas dari kalimat menurut sifatnya dan pada asasnya merupakan tugas Pemerintah Pusat.

Dalam pelaksanaan hak menguasai negara, Pemerintah Pusat dapat menguasakan (memberi kuasa) kepada Pemerintah Daerah, namun hal tersebut bukan suatu keharusan. Kata-kata "dapat dikuasakan" dan :'sekedar diperlukan" memberi tekanan bahwa pemberian kuasa kepada Pemeirntah Daerah bukan suatu keharusan. Dalam hubungan hukum, istilah dikuasakan mengandung beberapa komponen, yaitu :

a. Adanya pernyataan dari pihak yang memegang kewenangan untuk menyerahkan kewenangannya kepada institusi atau pihak lain yang ditunjuk. Dalam kaitannya dengan kewenangan hak menguasai negara, pihak yang memegang kewenangan adalah Pemerintah Pusat dan kemudian memberikan kuasa kepada Pemerintah Daerah untuk melaksanakan; 
b. Pihak yang menerima kuasa hanya boleh melaksanakan kewenangan itu sebatas apa yang tersebut dalam pernyataan penyerahan. Artinya pihak ini tidak boleh melaksanakan kewenangan selain yang diserahkan atau tidak boleh melampaui kewenangan yang diserahkan. Pemerintah Daerah tidak boleh melaksanakan kewenangan selain yang secara tegas diserahkan kepadanya;

c. Pihak penerima penyerahan harus mempertanggungjawabkan pelaksanaannya kepada pemberi kewenangan. Dalam hal ini, Pemerintah Daerah harus memberi pertanggungjawabannya kepada Pemerintah Pusat. ${ }^{8}$

Kalau dicermati secara seksama, kewenangan hak menguasai Negara atas tanah sebagaimana yang disebutkan dalam Pasal 2 ayat (2) UUPA dirumuskan dalam 2 (dua) kelompok istilah, yaitu "mengatur dan menyelenggarakan" dan "menentukan dan mengatur" bumi, air, dan ruang angkasa, termasuk kekayaan alam yang terkandung di dalamnya. Kata "mengatur" menunjuk pada kewenangan legistlatif pada Negara, sedangkan kata "menyelenggarakan" menunjuk pada kewenangan eksekutif.

Pelaksanaan tugas agraria yaitu asas soal agraria merupakan tugas Pemerintah Pusat. Asas ini sangat penting untuk mempertahankan dan melestarikan persatuan dan kesatuan bangsa, dan wilayah nasional Indonesia. oleh karena itu, tugas kewenangan di bidang pertanahan tidak boleh diotonomkan kepada daerah dan harus tetap ada pada Pemerintah Pusat. Pelimpahan sebagian kewenangan tersebut kepada daerah dapat dilakukan dalam bentuk medebewind. ${ }^{9}$ Hak menguasai oleh Negara yang pada intinya dirumuskan dalam Pasal 2 UUPA memberikan kewenangan untuk mengatur dan menetapkan berbagai segi penguasaan tanah yang sejak semula menurut sifatnya selalu dianggap sebagai tugas Pemerintah Pusat. Pengaturan dan penetapan tersebut yang meliputi perencanaan peruntukan tanah,, penguasaan dan perbuatan-perbuatan hukum mengenai tanah serta pendaftaran tanah, pelaksanaan ketentuan hukumnya pada

\footnotetext{
${ }^{8}$ Hartono Soerjopratiknjo, Perwakilan Berdasarkan Kehendak, Mustika Wikasa, Yogyakarta, 1994, h. 50 $-57$.

${ }^{9}$ Boedi Harsono, Op.cit., h. 272.
} 
asasnya selalu dilakukan oleh Pemerintah Pusat sendiri. Kalau pun ada pelimpahan kewenangan dalam pelaksanaannya, pelimpahan tersebut dilakukan dalam rangka dekosentrasi kepada pejabat-pejabat Pemerintah Pusat yang ada di daerah atau pun kepada Pemerintah Daerah dalam rangka medebewind, bukan otonomi daerah. ${ }^{10}$

Pasal 2 ayat (4) UUPA menegaskan bahwa hak menguasai Negara atas tanah dalam pelaksanaannya dapat dikuasakan kepada Daerah-daerah Swatantra (Pemerintah Daerah) dan masyarakat-masyarakat hukum adat sekedar diperlukan dan tidak bertentangan dengan kepentingan nasional. Ketentuan ini menunjukkan bahwa hak menguasai negara atas tanah merupakan wewenang Pemerintah Pusat, sedangkan Pemerintah Daerah dapat melaksanakan wewenang negara tersebut tidak bersifat otonom, melainkan bersifat pelimpahan kewenangan atau medebewind. Pelimpahan kewenangan tersebut sekadar diperlukan dan tidak bertentangan dengan kepentingan nasional.

Sebelum tahun 1999, kewenangan pengurusan bidang pertanahan ada pada Pemerintah Pusat yang bersifat sentralistik, sedangkan kewenangan Pemerintah Daerah melaksanakan kewenangan pengurusan bidang pertanahan berdasarkan pelimpahan kewenangan yang bersifat medebewind. Dengan kata lain, penyerahan kewenangan pengurusan bidang pertanahan kepada Pemerintah Daerah dibatasi hanya menyangkut kewenangan menyelenggarakan atau melaksanakan dan bukan kewenangan mengatur. Penyerahan kewenangan itupun didasarkan pada asumsi bahwa instansu di daerah yang melaksanakan kewenangan tersebut merupakan instansi Pemerintah Pusat yang ada di daerah dan bukan sebagai lembaga otonom daerah.

Dengan diundangkan Undang-undang No. 22 Tahun 1999 tentang Pemerintahan Daerah, yang di dalamnya mengatur otonomi daerah mengubah kebijakan kewenangan pengurusan bidang pertanahan, yang sebelumnya bersifat sentralistik diubah menjadi desentralistik. Otonomi daerah menghendaki adanya penyerahan kewenangan dari Pemerintah Pusat kepada Pemerintah Daerah dengan

\footnotetext{
${ }^{10}$ Arie S Hutagalung, Tebaran Pemikiran Seputar Masalah Hukum Tanah, Lembaga Pemberdayaan Hukum Indonesia, Jakarta, 2005, h. 40.
} 
pengertian bahwa kewenangan tersebut merupakan kepunyaan Pemerintah Daerah. Kebijakan otonomi daerah ditandai oleh lahirnya Undang-undang No. 22 Tahun 1999, yang mengubah hubungan antara Pemerintah Pusat dengan Pemerintah Daerah yang sebelumnya bersifat sentralistik diubah menjadi desentralistik. Kewenangan Pemerintah Pusat yang sebelumnya mencakup semua sektor pembangunan telah dikurangi menjadi hanya beberapa sektor strategis.

Dalam Undang-undang No. 22 Tahun 1999 ditetapkan bahwa tidak semua bidang pembangunan diserahkan kewenangannya oleh Pemerintah Pusat kepada Pemerintah Daerah. Bidang pembangunan yang tidak diserahkan kewenangannya oleh Pemerintah Pusat kepada Pemerintah Daerah, adalah politik luar negeri, pertahanan keamanan, peradilan, moneter dan fiskal, agama, serta kewenangan bidang lain. Kewenangan bidang lain meliputi kebijakan tentang perencanaan nasional dan pengendalian pembangunan nasional secara makro, dana perimbangan keuangan, sistem administrasi negara dan lembaga pereknomian negara, pembinaan dan pemberdayaan sumber daya manusia, pemberdayaan sumber daya alam serta teknologi tinggi yang strategis konversi, dan standardisasi.

Undang-undang No. 22 Tahun 1999 menetapkan 11 (sebelas) bidang pembangunan yang diserahkan kewenangannya oleh Pemerintah Pusat kepada Pemerintah Kabupaten/Kota, yaitu pekerjaan umum, kesehatan, pendidikan dan kebudayaan, pertanian, perhubungan, industri dan perdagangan, penanaman, lingkungan hidup, pertanahan, koperasi, dan tenaga kerja.

Kewenangan di bidang pertanahan yang menjadi salah satu bidang pembangunan yang diserahkan kewenangan oleh Pemerintah Pusat kepada Pemerintah Kabupaten/Kota menimbulkan kontroversi. Secara yuridis normatif, Undang-undang No. 22 Tahun 1999 mengamanatkan penyerahan kewenangan bidang pertanahan dari Pemerintah Pusat kepada Pemerintah Kabupaten/Kota, tetapi disisi lain Pemerintah sendiri dianggap tidak konsisten dengan menerbitkan Keputusan Presiden atau Peraturan Presiden yang isinya bertentangan dengan Undang-undang No. 22 Tahun 1999, sehingga menimbulkan dualisme hukum dan ketidakpastian hukum dalam pelaksanaan kebijakan bidang pertanahan. Dari 
aspek praktisnya, bidang pertanahan yang diserahkan kewenangannya oleh Pemerintah Pusat kepada Pemerintah Kabupaten/Kota tidak jelas, apakah seluruh kegiatan yang berkaitan dengan pertanahan, termasuk yang dilaksanakan oleh Badan Pertanahan Nasional, seperti kegiatan pendaftaran tanah, ataukah hanya kegiatan-kegiatan tertentu yang berkaitan dengan pertanahan.

Keputusan Presiden No. 34 Tahun 2003 dirasakan oleh Pemerintah Kabupaten/Kota mempersempit kewenangan pelayanan pertanahan yang sebelumnya sudah diatur dalam Keputusan Menteri Dalam Negeri dan Otonomi Daerah No. 50 Tahun 2000 tentang Pedoman Susunan Organisasi dan Tata Kerja Perangkat Daerah Kabupaten/Kota.

Undang-undang No. 22 Tahun 1999 dinyatakan tidak berlaku lagi oleh Undang-undang No. 32 Tahun 2004 tentang Pemerintahan Daerah. Dalam Undang-undang No. 32 Tahun 2004 ditetapkan bahwa salah satu urusan wajib yang menjadi kewenangan Pemerintah Daerah Provinsi dan Pemerintah Daerah Kabupaten/Kota adalah pelayanan pertanahan. Disisi lain, Pemerintah dalam hal ini Presiden menerbitkan Peraturan Presiden No. 10 Tahun 2006 tentang Badan Pertanahan Nasional Republik Indonesia. Tugas Badan Pertanahan Nasional Republik Indonesia adalah melaksanakan tugas Pemerintah di bidang pertanahan secara nasonal, regional, dan sektoral. Dengan diterbitkannya Peraturan Presiden No. 10 Tahun 2006, urusan pelayanan yang berkaitan dengan kegiatan pendaftaran tanah telah diselenggarakan oleh Badan Pertanahan Nasional, yang dalam pelaksanaannya dilakukan oleh Kepala Kantor Pertanahan Kabupaten/Kota sebagai tugas pembantuan atau medebewind. Peraturan Presiden No. 10 Tahun 2006 juga mengurangi kewenangan Pemerintah Provinsi atau Pemerintah Kabupaten/Kota dalam melaksanakan urusan pelayanan pertanahan dan substansinya bertentangan dengan Undang-undang No. 32 Tahun 2004.

Terbitnya Peraturan Pemerintah No. 38 Tahun 2007 menegaskan urusan pertanahan apa saja yang wewenangnya diserahkan kepada Pemerintah Provinsi, dan Pemerintah Kabupaten/Kota. Urusan pertanahan yang diserahkan kepada Pemerintah Provonsi dan Pemerintah Kabupaten/Kota ada 9 (Sembilan) bidang. 9 (Sembilan) bidang urusan pertanahan yang diserahkan kepada Pemerintah 
Provinsi dan Pemerintah Kabupaten/Kota yang tercantum dalam Lampiran Peraturan Pemerintah No. 38 Tahun 2007 merupakan salinan dari Keputusan Presiden No. 34 Tahun 2003. Dengan demikian, urusan pelayanan pertanahan yang berkaitan dengan kegiatan pendaftaran tanah tetap diselenggarakan oleh Kepala Badan Pertanahan Nasional Republik Indonesia, yang dalam pelaksanaanya dilaksanakan oleh Kepala Kantor Pertanahan Kabupaten/Kota.

\section{PENUTUP}

Kewenangan di bidang pertanahan merupakan wewenang Pemerintah Pusat. Wewenang tersebut diselenggarakan oleh Kepala Badan Pertanahan Nasional Republik Indonesia, dalam pelaksanaannya dilakukan Kepala Kantor Pertanahan Kabupaten/Kota, yang merupakan tugas pembantuan atau medebewind. Ada urusan pertanahan yang didesentralisasikan oleh Pemerintah kepada Pemeringtah Kabupaten/Kota, yaitu meliputi pemberian izin lokasi, penyelenggaraan pengadaan tanah untuk kepentingan pembangunan, penyelesaian sengketa tanah garapan, penyelesaian masalah ganti kerugian dan santunan tanah untuk pembangunan, penetapan subyek dan obyek retribusi tanah, serta ganti kerugian tanah kelebihan maksimum dan tanah absentee, penetepan dan penyelesaian masalah tanah ulayat, pemanfaatan dan penyelesaian masalah tanah kosong, pemberian izin membuka tanah, perencanaan penggunaan tanah wilayah kabupaten/kota.

\section{DAFTAR PUSTAKA}

Hadjon, Philipus M, Pengantar Hukum Administrasi di Indonesia, Gadjah Mada University Press, Yogyakarta, 2005.

Harsono, Boedi, Hukum Agraria Indonesia Sejarah Pembentukan Undangundang Pokok Agraria, Isi, dan Pelaksanaannya, Djambatan, Jakarta, 2003.

Hutagalung, Arie S, Tebaran Pemikiran Seputar Masalah Hukum Tanah, Lembaga Pemberdayaan Hukum Indonesia, Jakarta, 2005. 
Ismail, Nur Hasan, "Otonomi Bidang Pertanahan : Reposisi Peranan Pusat dan Daerah, dan Ideologi Politik Pertanahan", Makalah, Fakultas Hukum Universitas Gadjah Mada, Yogyakarta, 2000.

Marbun, S.F., Peradilan Administrasi Negara dan Upaya Administratif di Indonesia, Liberty, Yogyakarta, 1997.

Murhaini, Suriansyah, Kewenangan Pemerintah Daerah Mengurus Bidang Pertanahan, Laksbang Justitia, Surabaya, 2009.

Soerjopratiknjo, Hartono, Perwakilan Berdasarkan Kehendak, Mustika Wikasa, Yogyakarta, 1994.

Ketetapan MPR RI No. IX/MPR/2001 tentang Pembaruan Agraria dan Pengelolaan Sumber Daya Alam.

Undang-undang No. 5 Tahun 1960 tentang Peraturan Dasar Pokok-pokok Agraria.

Undang-undang No. 22 Tahun 1999 tentang Pemerintahan Daerah.

Undang-undang No. 32 Tahun 2004 tentang Pemerintahan Daerah.

Peraturan Pemerintah No. 38 Tahun 2007 tentang Pembagian Urusan Pemerintahan Antara Pemerintah, Pemerintahan Daerah Provinsi dan Pemerintahan Daerah Kabupaten/Kota. 